\title{
PIECE WORK PAY AND HOURLY PAY OVER THE CYCLE
}

\author{
ROBERT A. HART \\ January 2007 \\ Department of Economics \\ University of Stirling \\ Stirling FK9 4LA \\ Email: r.a.hart@stir.ac.uk
}

\begin{abstract}
This paper investigates the relative cyclical behavior of the pay of piece workers and hourly paid workers. It uses a unique data set of blue-collar workers in British engineering between 1926 and 1966. The statistics are obtained from the payrolls of firms belonging to the Engineering Employers Federation (EEF).

Roughly, the EEF accounted for one-third of the total engineering workforce. The data consist of cell averages delineated by 15 occupations in 29 engineering districts. Via a firm-union bargaining modelling structure, the question is examined as to likely earnings responses to price shocks under the two payment systems. The empirical work entails testing for cyclical differences in the two payments methods Insights are gained from distinguishing between the relatively tight post-war and slack pre-war labor markets.
\end{abstract}

Key words: Piece work pay, hourly pay, business cycle

JEL: E32; J31; J33

Acknowledgements: Data collection and empirical work was funded by ESRC Grant RES-000-22-0860. I am grateful to the Engineering Employers Federation for allowing access to their payroll statistics and to Warwick University Modern Record Centre and Glasgow University Archive Centre for their help in assembling the material. Adele Redhead (Glasgow) and Christine Woodland (Warwick) were especially helpful. Thanks to Andrew Currall for transcribing the data and to Elizabeth Roberts for her excellent research assistance. Paul Devereux, Olaf Hübler, Uwe Jirjahn, Thomas Moutos and Paul Ryan gave me very helpful comments and criticisms on earlier drafts of the paper. I retain all responsibility for subsequent errors. 


\section{Introduction}

Over the past two decades researchers have found evidence of strong wage procyclicality. In most cases, this has been measured in terms of wage - unemployment trade-offs. ${ }^{1}$ But the picture is not clear cut. Based on U.S. data from the Panel Study of Income Dynamics (PSID), Devereux (2001) finds relatively modest overall wage procyclicality. His study differentiates among salaried and hourly paid workers as well as workers whose pay is directly related to current output. Forms of remuneration for this last group comprise "piece rates, commissions, tips, and in other ways". Hourly earnings linked directly to current output (such as piece rates) are found by Devereux to be significantly more procyclical than those of hourly paid or salaried workers. However, the group of individuals receiving piece rates/commissions etc. in the PSID is relatively small and so Devereux is very cautious about this relative finding.

Since output-related pay is likely to correlate positively with productivity and product demand, we might expect a priori an especially strong positive association between piece rate pay and the level of business activity. This paper attempts to examine the question of cyclical movements in incentive pay and time-related pay in more depth. It concentrates on the two types of remuneration of blue collar workers in the British engineering industry between 1926 and 1966. These are earnings based on piece rates and on hourly rates. Data are compiled from the annual payroll records of the Engineering Employers Federation (EEF). In the early 1950s, total engineering

\footnotetext{
${ }^{1}$ Following the study of Bils (1985), empirical research has been dominated by the use of individual-level panels. Findings of strong cyclicality include Solon et al. (1994) and Shin (1994) for the United States, Bellmann and Blien (2001) for Germany, Devereux and Hart (2006) and Hart (2006) for the U.K. While inevitable caveats arise in these studies, they are all reasonably consistent with an emerging stylized fact that a one point increase in the rate of unemployment is associated with a one percent decrease in the wage.
} 
employment accounted for about one seventh of Britain's working population (Knowles and Hill, 1954). Federated engineering firms accounted for about one-third of this total. The payroll statistics used here cover roughly 40 percent of the EEF employment. They consist of cell averages of 15 engineering occupational groups within 29 engineering geographical districts over a 40-year time span. Matching district unemployment rates are also available.

The engineering industry in general and, especially, the EEF were heavily unionized. Accordingly, the paper starts by investigating piece-and hours-related pay reactions to price or productivity shocks within a firm-union bargaining framework. Linked to modeling outcomes, pay cyclicality is subsequently tested under two unemployment regimes. In tight post-war labor markets, with relatively little short-term scope to change the size of the firm's employment stock, significant increases in production are more likely to stem from increases in the hours and effort of existing workers. Earnings increases directly rewarded existing employees for this greater work intensity as well as compensating them for increased work disutility. In slack pre-war market conditions, changes in union utility was strongly influenced by rises and falls in employed union membership with earnings' effects becoming less clear cut.

The EEF data offer a number of comparative empirical advantages. First, they contain large samples of both piece-rate and hourly paid workers and so provide serious insights into cyclicality by these two radically different payment methods. Second, by straddling the period of the Great Depression, they enable us to obtain evidence derived from the most pronounced and unequivocal business cycle. Third, they cover a fairly homogeneous group of workers so that any observed differences by method of pay are 
less likely to be spuriously caused by differences in worker characteristics. Fourth, unlike earlier studies that examine pre-war wage cyclicality, the data permit the use of modern micro methods to study cyclicality. This enables comparison with findings of studies using more recent data. Fifth, hours' fluctuations, and associated variations in the importance of overtime pay, are important features of engineering blue collar jobs and so the data helps cast a sharp light on the role of working time in earnings cycles (see Abowd and Card, 1989, Devereux, 2001, Shin and Solon, 2004). Sixth, the data offer a stringent test of whether the common finding of strong wage procyclicality is time invariant or just relevant to recent decades. For example, on the basis of industry-level data for the U.S., Bernanke and Powell (1986) find that post-war wage procyclicality contrasts, typically, with countercyclical real wages in the pre-war period (see also Bernanke, 1986).

Section 2 outlines firm-union bargaining outcomes under piece- and time- related payment systems. Section 3 contains a description and discussion of EEF and related data. Section 4 lays out the approach to estimating pay - unemployment cyclicality. Results are presented in Section 5. Brief conclusions are drawn-up in Section 6.

\section{Payment methods, firm-union bargaining, and price shocks}

Union agreements formed an important part of pay settlements within EEF member firms. Discussion here focuses on a firm-union bargaining agenda that includes pay (either piece- or time- related), work intensity (defined by hours and effort), and employment. Embracing both pay and work intensity also reflects the framework of most of the empirical cyclical pay literature listed in the introduction (see Foonote 1). During the study period, engineering unions cared not only about pay and other internal work 
conditions but also about the proportion union members who were employed. ${ }^{2}$ I focus on piece- and time-rate reactions to price shocks within an efficient bargaining framework.

Consider an engineering firm that produces homogeneous output, Q, and chooses to operate under either a piece rate system or an hourly pay system. ${ }^{3}$ Workers belong to a single union. The union also represents outside unemployed workers. It is assumed that the union is risk neutral.

The firm's production function is given by (1) $Q=F(N, h, e) F_{i}>0, F_{i i}<0$

where $N$ is the workforce, $h$ is average hours, and $e$ is average work effort.

The firm's profit is given by ${ }^{4}$

(2) $\pi=p Q-\left(Y^{J}-z\right) N \quad(J=P, H)$

where $p$ is product price, $Y$ is earnings, $z$ is the per-worker cost of monitoring performance, with earnings relating either to a piece rate system $(P)$ or an hourly pay system $(H)$. For simplicity, I assume fixed and predetermined per-worker expenditures by the firm on monitoring.

How are the two payments methods differentiated?

\footnotetext{
${ }^{2}$ This was especially true of the Great Depression when up to one-quarter of the entire engineering workforce was unemployed.

${ }^{3}$ The simplification of assuming that the firm wholly employs piece rate or hourly paid workers is not too unreasonable a restriction in the context of the EEF data used in the subsequent empircal analyis. Hill and Knowles (1956) were able to obtain individual firm data from the EEF for 1952. They found that fitters were paid exclusively by time rates in 60 percent of firms, exclusively by piece rate in 17 percent, and by a mixture the two payment methods in the remainder.

${ }^{4}$ To simplify the notation, I differentiate between the two payment systems by suffixing earnings without indicating that the respective output, profits, and fixed costs are likely to differ.
} 
Following Pencavel (1977), let the output or performance of a piece rate worker be indexed by $\Phi$. Let the level of $\Phi$ be determined by the number of hours worked and the effort expended on that work. Then we may express piece-related earnings as

(3) $Y^{P}=\tau \Phi(e, h)$

where $\tau$ is the piece rate.

Earnings based on paid-for hours may be expressed simply as

(4) $Y^{H}=y^{H} h$

where $y^{H}$ is hourly wage earnings. With no overtime, $y^{H}=w$ where $w$ is the basic wage rate. With overtime $y^{H}=w h_{s}+k w\left(h-h_{s}\right)$ where $h_{s}$ is maximum basic weekly hours and $k$ $(>1)$ is the overtime premium. Where overtime is worked, an increase in $h$ for given $h_{s}, w$ and $k$ will increase $Y^{H}$.

The essential differences between the piece rate and hourly pay set-ups relate to the definition and treatment of effort, $e$. Most obviously, $e$ directly affects earnings of pieceworkers but not timeworkers. ${ }^{5}$ Piece work earnings relate to current output (see Lazear, 1986) with the latter implicitly assumed here to be a function of work application or effort. So, for given $h$ and $\tau$ in (3), a pieceworker can earn more one week compared to another week by increasing current output and/or by ensuring that a larger proportion of output achieves a laid-down quality standard. By contrast, the hourly pay of a time worker is typically fixed by a short term contractual agreement. Of course, productive effort may vary and impact on output - as expressed in equation (1) - in a time work firm. For example, shirking is a potential problem among hourly paid workers. Essentially,

\footnotetext{
${ }^{5}$ Although it can indirectly affect the remuneration of both groups due to rent sharing via productive activity.
} 
therefore, monitoring costs related to productive performance (i.e. the $z$ 's in (2)) have different areas of emphasis under the two payment systems. As stated by Pencavel (1977), "supervisory personnel are used to reduce shirking by workers on time-rates while with payment-by-results systems more resources are devoted to inspect the quality of output...."

The trade union has $M$ members of whom $M-N$ are unemployed and receive $b$ unemployment benefit. The union's objective function is given by

(5) $V=N\left\{u\left(Y^{J}\right)-d(e, h)\right\}+(M-N) u(b)$

where we assume that a worker's disutility is separable in income and the disutility of work, with $d(e, h)$ representing the latter. We assume that $d_{i}>0$ and $d_{i i}>0$. If bargaining breaks down, utility at the threat point is $U=M u(b)$. The assumption of risk neutrality implies $u^{\prime}>0$ and $u^{\prime \prime}=0$.

The union's rent is $R=V-U$. The risk assumption allows us to express rent simply in terms of net income. Thus

(6) $R=N\left\{Y^{J}-d(e, h)-b\right\}$.

The generalised Nash bargain is given by

(7) $\max _{N, h, e, Y^{J}} \Pi=(\pi)^{1-\alpha}(R)^{\alpha}$

where $\alpha$ is relative union power, with $\alpha \in\{0,1\}$.

From the first-order conditions to the problem in (7), the union's share of rent is given by $N\left\{Y^{J}-z-d(\cdot)-b\right\}=\{\alpha /(1-\alpha)\} \pi$. Further, we obtain $p F_{N}=\{z+d(\cdot)+b\}$ or the parties equate marginal value product and the marginal cost of employment, with $d(\cdot)$ 
and $b$ representing the opportunity cost of work. On the intensive margins, equilibrium requires that $\left(F_{h} / F_{e}\right)=\left(d_{h} / d_{e}\right)$, or relative returns and disutilities of hours and effort are equated.

From (6) the union's rent is increased by a rise in employed membership and/or net income. What are the effects of a price, or productivity, shock on these two variables? This involves evaluating $\partial N / \partial p, \partial e / \partial p, \partial h / \partial p$, and $\partial Y^{J} / \partial p$.

As an initial simplification, suppose that changes in effort have no effect on individual and aggregate output (i.e. $\Phi_{e}=F_{e}=0$ in (3) and (1), respectively). This may be a plausible assumption in respect of the work environment of many engineering workers. First, the use of automatic machinery may serve to regulate and control the rate of work flow. Second, engineering work linked to line production may remove individuals' abilities to influence the rate of production throughput. Third, team work may severely restrict individual control of work rate when output stems from interdependent inputs across team members. It should be added, however, that discounting effort effects in these ways is a much more plausible assumption in a time work compared to a piece work environment. Tightly controlling individuals' abilities to vary output as well as involvement in team-reliant production are operational features that detract from the use of piece rate systems (Fama, 1991). ${ }^{6}$

Imposing this effort restriction effectively reduces the problem to that of a workers-hours efficient bargaining model (see Hart and Moutos, 1995; pp. 119-121). Even with this simpler problem, however, it is not possible to sign unambiguously the

\footnotetext{
${ }^{6}$ Also, since time rated work is unlikely to involve close monitoring of current individual output, the firm may realistically endeavour to ensure minimum output levels that involve relatively simple and inexpensive monitoring procedures (Borjas, 2002). In this event, it is realistic to confine attention to hours of work as the representation of the time-work firm's intensive margin of operation.
} 
reactions of employment or hours or earnings to price changes. In essence, a positive price shock will result in increases in production and profit. But increased factor input may take the form of a rise in employment or hours or both. The union's payoff also rises, but this can take the form of a rise in employed membership and/or a rise in earnings. In fact, a significant rise in one these utility-related variables may accompany a fall in the other.

Retaining the assumption of no association between effort changes and output, two additional restrictions do lead to more clear cut outcomes. First, in respect of (4), let hours be fixed at $h=h_{s}$ (and disutility at equivalent $\mathrm{d}=\mathrm{d}_{\mathrm{s}}$ ). The firm and the union may have a long-term agreement that workers operate on maximum basic weekly hours. ${ }^{7}$ The modified problem in (7) now yields $d N / d p>0$ and $d Y^{J} / d p=\frac{>}{<} 0 .{ }^{8}$ A favorable price shock induces the firm to increase production which, in this special case, is limited to an increase in workforce size. From (6), the union's rent is enhanced. Whether or not the union additionally gains through an increase in the wage is not certain. ${ }^{9}$ Second, suppose that employment is fixed at $N=\bar{N}$. Similar developments to the above produce $d h / d p>$

\footnotetext{
${ }^{7}$ Maximum basic weekly hours where negotiated at national level and applied generally to British engineering over the period of study. Between 1919 and 1946 the basic workweek was 47 hours. It reduced to 44 hours from 1947 to 1959, to 42 hours between 1960 and 1964, and to 40 hours between 1965 and 1968 .

${ }^{8}$ Take the example of time payments, with $Y^{H}=w$ in (4) and with $h=h_{s}=1$ by choice of units. Totally differentiating the first-order conditions to this problem yields $d N / d p=F_{N} N / \Delta>0$ and $d w / d p=$ $\left\{-F_{N}\left(w-d_{s}-b\right)-a F(N) p F_{N N}\right\} / \Delta \geq 0$ where $\Delta=-N p F_{N N}>0$.

${ }^{9}$ It also holds that $d N / d b<0$ and $d w / d b>0$, or a fall in unemployment benefit persuades the union to trade-off more employed members at lower pay. Also we find that $d N / d z<0$ while $d w / d z \geq 0$. Moreover, $d N / d \alpha=0, d w / d \alpha>0$ or a fall in relative union power leaves employment intact (although the firm's share of rent rises) while reducing the wage.
} 
0 and $d Y^{J} / d p>0 .{ }^{10}$ Now, increased production, accompanying a positive price shock, is achieved through a rise in average hours. In this case, increased union utility is unequivocally achieved via an increase in the piece rate or the wage rate.

What if we allow changes in effort to affect individual and aggregate output (i.e. $\Phi_{e}, F_{e}>0$ in (3) and (1), respectively)? Unsurprisingly, given the foregoing, it is not possible to find unambiguous employment, hours and earnings responses to price shocks. An added complication is that both effort and hours appear in the production and worker disutility function of piecework and timework firms and, additionally, in the earnings function of piecework firms. These two intensive margin variables may act as complements or substitutes. In the latter case, for example, a decision to increase hourly effort may produce an offsetting leisure reaction, represented by a reduction in the number of weekly hours on the job. Gauging relative factor input and earnings responses in this case is renderred especially difficult. ${ }^{11}$

However, one additional useful insight arises from the complete problem. The possibility that effort and hours act as substitute inputs to price shocks underscores the usefulness of empirically measuring pay responses to changes in demand in terms both of hourly and weekly earnings. Consider the outcome $\partial Y^{P} / \partial p>0$ where $Y^{P}$ in (3) is defined as the weekly earnings of a pieceworker. For given $\tau$ in (3), two possible scenarios are as follows. Suppose that a positive price shock causes a change in effort and a partially offsetting reduction in hours such that weekly earnings increase by a given

${ }^{10} d h / d p=F_{h} \bar{N} / \Delta>0$ and $d Y_{J} / d p=\left\{F_{h} \bar{N} d^{\prime}(h)+\alpha F(\cdot) \bar{N} d^{\prime \prime}(h)-\alpha F(\cdot) p F_{h h}\right\} / \Delta>0$ where $\Delta=\bar{N}\left(\bar{N} d^{\prime \prime}(h)-p F_{h h}\right)>0$.

${ }^{11}$ See the very useful discussion in Pencavel (1977) in relation to a highly related supply-side problem. 
amount. Alternatively, consider an equivalent weekly earnings response but this time consisting of a positive hours effect with a partial offsetting reduction in effort. While weekly earnings changes are the same, by assumption, the rise in average hourly earnings in the first of these scenarios would exceed the rise in the second. In essence, unobserved effort may be associated with different hourly/weekly earnings responses. ${ }^{12}$

\section{Remarks}

Incorporating hours and effort into the definitions of production, utility and remuneration does not lead to clean-cut tractability in modelling outcomes.

Unambiguous employment and earnings responses require the imposition of rather stringent restrictions. Four points are worth stressing.

(a) In a union bargaining framework, where the union 'cares' about the employment of its members, it is not possible to establish systematic differences in the earnings responses of piece- and time-work firms to price, or productivity, shocks.

(b) Even if we assume that effort is independent of output changes, bargaining over employment and hours does not ensure unambiguous earnings responses.

(c) Retaining the effort assumption in (b) and holding employment fixed does produce positive earnings responses to price shocks. A reasonable inference follows from this result. Suppose that a positive price shock occurs during tight labor market conditions. For many firms, associated production increases are

\footnotetext{
${ }^{12}$ Distinctions among the hourly wage, earnings divided by hours, and earnings are very important to the approaches of Devereux (2001) and Shin and Solon (2004).
} 
more likely to derive from increased intensive margin activity. Such changes, may well impact positively on earnings as firms reward longer hours and greater effort, including compensating employees for associated rises in work disutility.

(d) Especially in the case of pieceworkers, it is good practice to distinguish between hourly earnings and weekly earnings in empirical work since the relationship between effort and hours may be such as to render the responses of the two variables to differ for given price shocks.

\section{Data and descriptive statistics}

Data for this project, conditioned by the availability of district unemployment rates, cover the period from 1926 to 1938 and from 1951 to $1966 .{ }^{13}$ Between 1926 and 1938, the EEF represented between 1,800 and 2,200 firms employing between 260,000 and 560,000 adult manual workers (Wigham, 1973). Between 1951 and 1966, there were between 4,000 and 4, 700 member firms employing between 1,000,000 and 1,161,000 manual workers. The EEF asked each of its member firms to conduct annual earnings enquiries based on company payrolls and during a specimen week $^{14}$ - separately for timeworkers and pieceworkers. Data on the two types of payment groups are available for 9 main occupations. ${ }^{15}$ All are used in this study although several are further subdivided by skill

\footnotetext{
${ }^{13}$ There are no wage and hours data for 1957 and 1963.

14 During the inter -war period the specimen week always occurred in October. In the post-war period, the data were recorded during March 1958, May 1952 and otherwise during one of the months from June to October.

${ }^{15}$ These are coppersmiths, fitters; machinemen; moulders, patternmakers, platers/riveters/caulkers; sheet metal workers; turners, and labourers. The EEF earnings enquiries did not exhaustively cover all engineering occupations. For example, they exclude workers engaged on maintenance and repair. The 9
} 
level, giving 15 occupational groups in total (see Table 1). Pay data allow for the calculation of basic wage rates (i.e. excluding overtime) of hourly paid workers. Average hourly earnings, average weekly earnings as well as average weekly hours are available for both hourly paid workers and pieceworkers. All pay and occupational statistics are further broken down by EEF into over 50 engineering geographical districts, many of which are travel-to-work areas. This study makes use of 29 of these (see Table 1), for which exactly matched district male unemployment rates are available. ${ }^{16}$

\section{Table 1 here}

During the study period, collective bargaining over pay and conditions was an important aspect of the British engineering industry. The dominant union was the Amalgamated Engineering Union (AEU) but several smaller unions also negotiated on behalf of engineering workers. There is no direct information on the proportion of unionized workers in federated firms but it is safe to infer that they were significantly more unionized than firms in the (relatively highly unionized ${ }^{17}$ ) industry as a whole. Wigham (1973, pp 5-8) identifies three basic functions of the Federation that remained unchanged throughout the period. First, it provided collective support in order to protect individual firms from being singled out in union actions. Second, it aimed to preserve the

recorded occupations accounted for between 40 and 50 percent of manual males employed in federated firms.

16 The unemployment rates are obtained from Hart and MacKay (1975). They were constructed to coincide with EEF districts by combining data on male unemployment and total insured workers taken from the Local Unemployment Index and from other records provided by the Department of Employment.

\footnotetext{
${ }^{17}$ Historical union density data (i.e. actual union membership as a percentage of potential union membership) for the industry as a whole (i.e. covering federated and non-federated firms) are available in Bain and Price (1980). In the post-war period, the densities were uniformly high, lying between 50 and 57 percent. They were considerably lower in the pre-war period, and significantly more counter-cyclical. Between 1924 and 1933 they fell from 34 to 24 percent and then rose to 33 percent in 1938.
} 
relative power of employers to make management decisions. Third, it helped towards conflict resolution in union disputes. Moreover, EEF membership was skewed significantly towards large firms where union membership and participation would be expected to be relatively high. ${ }^{18}$

The detailed payroll statistics on which estimation here is based were collected for the prime purpose of being of direct use in union negotiations. While national level bargaining was important - especially in respect of attempting to set minimum pay rates in key occupations - final agreed rates were strongly influenced at both district and company levels. ${ }^{19}$ Piece rate pricing was complex and displayed considerable variation across this large and heterogeneous industry. Nonetheless, there were attempts at establishing relatively simple pricing guidelines. Based on a worker with 'average ability', national agreements established a percentage mark-up that a pieceworker might be expected to earn compared with the basic time rate within the same occupation.

Generally, however, such rules provided no more than weakly enforced guidelines. Piece rate/time rate differentials varied substantially within firms, across firms and through time.

\footnotetext{
${ }^{18}$ In their detailed analysis of the 1953 EEF returns, Hill and Knowles (1956) show that while 50.7 percent of federated firms employed fewer than 100 workers they accounted for only 6.2 percent total employment. By contrast, the 1.8 percent of firms that employed over 3000 employees accounted for 27 percent of total employment.

${ }^{19}$ There were national agreements that determined two key occupational rates - for fitters and laborers. These were used to establish relative wages for other occupations. But there were a multiplicity of districtand company-level deviations from these national rates in order to accommodate local market conditions. As stated by Knowles and Hill (1954): "All rates fixed by national agreement are essentially minima, the national-agreed differentials may be disturbed or even inverted by firms paying more than the minima all round".
} 
"Owing to the immense number of different processes and operations in so heterogeneous an industry, as well as to the rapidity of technical development, any general control over piece-work earnings can be no more than minimal...Pieceworkers' actual earnings depend...on a vast number of particular piecework prices and times. These are settled by domestic bargaining and are subject to no national control except that implied by the application of the piecework percentage to the basic rate..." (Knowles and Hill, 1954, pp. 281 and 284).

\section{Figure 1 here}

Estimation is undertaken for the complete period 1926 - 1966 as well as for the pre-war (1926 - 1938) and post-war (1951-1966) periods. It is claimed in the previous section that cyclical wage behavior may be influenced by the relative tightness of labor markets. In the pre-war period, which straddles the Great Depression, the weighted average unemployment rates over the 29 districts used here was 10 percent in 1927, rising to 25.5 percent in 1932 before falling to 12.9 in 1938 . In 1931,14 of the 29 districts experienced unemployment rates in excess of 25 percent. In this year, the highest rate was 41.5 percent in Oldham and the lowest was 10 percent in Bedfordshire. In the postwar era, no district experienced a rate over 6.5 percent. The lowest aggregate annual rate was 1 percent in 1955 and the highest was 2.9 percent in 1963. Figure 1 shows the (weighted) aggregate rate together with a selection of district rates. Oldham in the north of England suffered particularly severely in the Great Depression while Bedfordshire in the south was least affected. London also fared relatively well while Manchester lay quite near to the mean line. It should be noted, however, that even in the post-war period 
relative unemployment differences among districts could be high; in many years rates of under 1 percent in southern and midland districts contrasted with 3, 4 and 5 percent in the most depressed northern districts.

\section{Figure 2 here}

Table 1 gives the mean number of workers in each district - piece and time workers taken separately over all occupations - with respect to the entire period as well as the two sub-periods. The very large standard deviations are easily explained by a representative example. Thus, within the EEF in 1958 there were 5930 skilled fitters in Coventry at one end of the spectrum and 31 fitters in St. Helens at the other. In the estimation that follows, all occupations by district with more than 10 workers are included. Table 1 also reveals that, on average, 59 percent of workers over the whole period worked under a piece rate system. Annual breakdowns of these percentages are shown in Figure 2 where it can be seen that pieceworkers rose as a group from 51 percent in 1926 to a peak of 65 percent in 1948, maintained a plateau to 1958, and then declined to 55 percent in 1966 .

Table 1 also shows mean real hourly and weekly earnings changes, reflecting the constructions in the subsequent empirical work. For the whole period, piecework and timework average pay changes are very similar. Comparing the pre- and post-war periods, significant pay changes occur in respect of weekly earnings. For both piecework and timework, weekly earnings changes are significantly smaller in the pre-war compared to the post-war years. This reflects in part a lower influence of overtime working in the 
former period. In the early 1930s, engineering workers experienced significant shorttime working, especially in the more depressed northern districts.

What about pay differentials between piece-rated and hourly-rated workers? To investigate this issue, I concentrate on hourly earnings. In common with all related studies, the differentials favor pieceworkers. Table 1 shows that, over the complete period, the average differential was 25 percent. However, this declined dramatically between the inter- and post-war periods, from respective period averages of 32 to 16 percent. The differentials exhibited a trend decline from 42 to 15 percent between 1926 and 1938 before rising to 40 percent at the peak of the war activity in $1942 .^{20}$ The build up to war (starting in 1935) and the early war years almost certainly produced a greater emphasis towards incentive-based pay designed to elicit greater commitment and effort. Post-war, differentials of 21 percent in 1948 declined almost monotonically to 11 percent by $1966 .{ }^{21}$ What is the pattern of the average hourly earnings piece/time differentials over the entire period conditioned by occupation, district and time? It is obtained as follows. The differential of pieceworkers and timeworkers in occupation group $i$ and district $r$ at time $t$ is expressed

\footnotetext{
${ }^{20}$ From 1914, piecework prices were fixed so that the average pieceworker could expect to earn about onethird more than the basic time rate. This was changed to one-quarter above the time rate in 1931. Other complicating factors - for example, interpreting the so-called National Bonus as applied to time and piece rates - are explained in Knowles and Hill (1954). These authors also give some explanation as to why the differential declined after WWII. There is a well established market-led literature on why we would expect wage differentials in favor of piece rates to result from more able workers self-selecting into and enjoying higher earnings than timeworkers (Lazear, 1986; Brown, 1990). Empircal studies tend to bear out these predictions (e.g. Pencavel, 1977; Seiler, 1984). It is not clear the extent to which these national guidelines merely reflected the inevitability of these sorting tendencies or indicated wider considerations. It is certainly difficult to square the post-war narrowing of the differentials with this economics literature.
}

\footnotetext{
${ }^{21}$ For most of this period, Knowles and Hill (1954) show corroborating differentials for the two blue-collar occupations of fitters and laborers.
} 


$$
\log y_{i r t}^{P}-\log y_{i r t}^{H}=d_{i}+d_{r}+f_{t}+e_{i r t}
$$

where $y^{P}$ and $y^{H}$ are average hourly earnings (piece-rate and hourly pay, respectively) and where $d_{\mathrm{i}}$ are occupation intercepts, $d_{r}$ are district intercepts ${ }^{22}, f_{t}$ are time intercepts, and $e_{i r t}$ is an error term.

\section{Figure 3 here}

Figure 3 shows plots of estimated time dummies from equation (8) (i.e. $\hat{f}_{t}$ ) using the complete data set. As background, a plot of the weighted average unemployment rate $(U)$ - based on the 29 engineering districts indicated in Table 1 - is also added. Over the Great Depression, the earnings differentials provide a very striking mirror image of the superimposed plot of unemployment. Average hourly earnings based on piece rates fell relative to their time rate equivalents during downturns in economic activity and rose during upturns. A steep decline in the differentials coupled with low aggregate unemployment rates are clearly the key post-war features.

\section{Estimation methodology}

Here, I evaluate the effects of separating piece rate and hourly paid workers in pay-unemployment relationships. For comparative purposes, following the majority of papers in the relevant literature, I begin by using a single national unemployment rate as a measure of the cycle. I adopt the two-step estimation procedure of Solon, Barsky and

\footnotetext{
${ }^{22}$ Different geographical engineering districts specialised in different types of engineering activity. For example, aircraft and motor vehicle manufacture concentrated in the West Midlands, textile engineering in Lancashire and Yorkshire, and marine engineering in the North East Coast of England, North West Coast of England and Scotland.
} 
Parker (1994). This is designed to tackle the following problem. Unlike the wages data, the national unemployment rate does not differentiate among engineering districts and occupational groups. Across and within districts different occupations may share common components of variance that are not captured by the single unemployment rate. This may serve to bias downwards the estimated unemployment standard errors (Moulton, 1986).

To illustrate the methodology, take the hourly real earnings changes of pieceworkers $\left(\Delta \log y^{P}\right)$ in occupation $\mathrm{i}$, within district $\mathrm{r}$, at time $\mathrm{t}$. Then the step 1 estimating equation is given by

(9) $\Delta \log y_{i r t}^{P}=\mathbf{d}_{i}+\mathbf{d}_{r}+\sum_{t=1}^{T} \chi_{t} d_{t}+\varepsilon_{i r t}$

where $\mathbf{d}_{i}$ and $\mathbf{d}_{r}$ are, respectively, sets of occupation and district dummies and where $d_{t}$ is a time dummy that is equal to 1 if the observation is from year $t$. The estimated coefficients on the time dummies, $\hat{\chi}_{t}(\mathrm{t}=1, \ldots, \mathrm{T})$, are regressed in step 2 on the change in the unemployment rate, $\Delta U$ and a time trend, YEAR:

$$
\hat{\chi}_{t}=\alpha_{1}+\alpha_{2} \Delta U_{t}+Y E A R_{t}+v_{t}
$$

I estimate (9) by OLS and (10) by weighted least squares (WLS) where the weights are the number of individuals represented in each year. The change in the log earnings is multiplied by 100 . The estimated coefficient $\alpha_{2}$ then reflects the percentage change in the wage for a one-point change in the unemployment rate.

This two step estimation procedure is also carried out separately with respect to timeworkers' real basic wage rate $(w)$ and average hourly earnings changes $\left(\Delta \log y^{H}\right)$ 
and to the pieceworkers' and timeworkers weekly average earnings $\left(\Delta \log Y^{P}\right.$ and $\Delta \log$ $Y^{H}$, respectively). Comparable weekly hours regressions (using $\Delta \log h$ ) are also carried out.

As we have seen from Figure 1, there are large variations in district unemployment rates and a natural extension of the foregoing is to disaggregate cyclical effects to this level (see also Devereux, 2001). We still need to make use of the two step method because within a given district different occupations may share common components of variance that are not captured by the district unemployment rates.

Again, illustrating with the case of pieceworkers, step 1 is given by

(11) $\Delta \log y_{i r t}^{P}=\mathbf{d}_{i}+\sum_{t=1}^{T} \sum_{r=1}^{R} \phi_{r t} d_{r t}+u_{i r t}$

where $d_{r t}$ denotes a dummy variable that takes the value of 1 for district $r$ at time $t$ (over $\mathrm{R}$ districts and $\mathrm{T}$ time periods) and $u_{i r t}$ is an error term.

In step 2, estimates of $\phi_{r t}$ are regressed on the change in district unemployment rates $\left(\Delta U_{r t}\right)$ plus district and time intercepts, that is

(12) $\hat{\phi}_{r t}=b_{1} \Delta U_{r t}+\mathbf{d}_{r}+\mathbf{d}_{t}+v_{r t}$.

Again, OLS is used to estimate (11) and WLS to estimate (12). The latter is weighted by the number of individuals in each district at time $t$. 


\section{Results}

Table 2 shows the national- and district-level second-stage estimates on the change in unemployment - i.e. regression equations (10) and (12) - for the complete period, 1926-1966. ${ }^{23}$ Results using national and district unemployment rates are quite similar. Unsurprisingly, breaking down unemployment into 29 districts reduces the standard errors of the estimated unemployment effects. Concentrating on the district results in the lower half of the Table, four features stand out.

First, while the hourly earnings of both pieceworkers and timeworkers are procyclical, the former display significantly larger coefficients than the latter. For pieceworkers, a 1 point increase in the unemployment rate is associated with a 0.25 percent decrease in the hourly earnings. The comparable earnings reduction for timeworkers is 0.09 . Second, the basic wage of hourly paid workers is acyclical. Comparing wage and hourly earnings results for this group suggests that hours, and hence the fraction of premium (overtime) to total pay, are procyclical. The third finding confirms this expectation. The hours of both piece rate and hourly paid workers are found to be strongly procyclical and not significantly different. A one point increase in the rate of unemployment is associated with a 0.5 percent reduction in weekly hours. Fourth, the importance of cyclical hours effects is confirmed, again for both types of workers, when weekly earnings replace hourly earnings. A one point increase in unemployment is associated with a 0.76 percent reduction in the weekly earnings of

\footnotetext{
${ }^{23}$ In all reported regressions, I also estimated the second stage entering current and lagged unemployment rates separately. In all cases, the pairs of estimated coefficients were statistically of equal size and opposite sign. This lends support to underlying wage (and hours) curves rather than Phillips curves.
} 
pieceworkers and a reduction of 0.63 percent for hourly paid workers, estimates that are not significantly different.

\section{Tables 2 and 3 here}

The results with respect to hourly paid workers in Table 2 are generally in line with equivalent results shown by Devereux (2001, Table 2 ). The hourly wage is acyclical. Earnings divided by hours are significantly procyclical, albeit with relatively modest quantitative importance in the present study. Weekly earnings display significantly greater procyclicality. Further, Devereux finds that average hourly earnings of job stayers receiving incentive pay - defined as "piece rates, commissions, tips and in other ways" - are considerably more procyclical than for hourly paid workers. The results in Table 2 give some limited support in this direction too. Thus, using district unemployment rates, the average hourly earnings of pieceworkers display significantly larger procyclical effects than those of timeworkers. But, the estimated pieceworker coefficient of -0.25 is considerably smaller than Devereux's equivalent job stayers' result of -2.17 .

I conjecture in Section 2, based on outcomes from restrictive modelling assumptions, that an increase in product price is likely to lead to greater positive earnings effects during generally tight labor market conditions. Over the pre-war period from1926 to 1938 , very large employment fluctuations occurred in engineering around a high trend in unemployment. Union utility was strongly affected by changes in employed membership with accompanying earnings outcomes less certain. During the post-war 
recovery period, while there were both time and cross section unemployment variations, the underlying labor market was altogether tighter with far less dramatic employment swings. Under these conditions, it is likely that earnings fluctuations may have been more sensitive to demand changes.

Table 3 presents separate results for the pre- and post-war periods, based on district-level unemployment rates. The pre-war results are not dissimilar from those for the full period shown in Table 2. The wage of hourly paid workers is acyclical. Piece rate workers' hourly earnings are significantly more procyclical than hourly paid workers. The weekly hours of both groups are highly procyclical and do not differ from one another. The hours fluctuations are clearly very important since both groups display significant and comparable earnings cyclicality.

In two important respects, the post-war period displays different outcomes. First, the cyclicality of the hourly earnings of hourly paid workers is significantly more pronounced that the earlier period (a 10-fold increase) ${ }^{24}$ Second, hourly earnings estimates do not differ statistically between the two payment groups. As for hours and weekly earnings responses, results from the post-war period correspond reasonably closely with the pre-war and total-period findings. Hours and earnings responses are strongly procyclical for both groups of workers. In fact, the weekly earnings coefficient estimates of about -1.0 are in line with the findings of most micro studies of earnings cyclicality that are based on more contemporary data sets.

\footnotetext{
${ }^{24}$ The estimated post-war wage rate coefficient (-0.33) is also considerably larger than the pre-war equivalent. However, in both cases, we cannot reject the hypothesis that estimated coefficients are different from zero.
} 


\section{Conclusions}

Since piece rate systems are geared to rewarding individuals' current output, it seems to be intuitively plausible that, compared to hourly pay, they should be more sensitive to cyclical fluctuations in productivity and product demand. The developments in Section 2 lead to the view that, in reality, it is very difficult to discern clear cut cyclical earnings differences between the two payments methods. In fact, in terms of weekly earnings, the subsequent empirical analysis finds no differences in earnings responses between the two groups.

In general terms, the findings of this paper lend support to Devereux (2001) who argues that it is important to distinguish between different payments measures in studies of earnings cyclicality. As in Devereux's study, hourly earnings responses are found to be less pronounced that those of weekly earnings. Also, it is found in the inter-war period that the wage of hourly paid workers is acyclical, average hourly earnings are significantly though weakly procyclical, and weekly earnings are far more strongly procyclical. Even in the post-war period, where the wage rate is found to be procyclical, weekly earnings are more strongly procyclical than either the wage or hourly earnings. An important explanation for these differences across measures derives from the underlying strong procyclical fluctuations in paid-for working time. Of course, we would expect more modest hours' responses in data sets that represent broader cross sections of occupations. Blue collar workers are especially prone to work paid overtime.

One further point is worth underlining. The findings here point to the possibility that cyclical earnings responses will differ according to the relative tightness of the labor market around which cyclical payment effects take place. Some background labor 
market motivation is presented via firm-union bargaining. Certainly, in the case of hourly paid workers, weak wage and hourly earnings responses in the inter-war perod contrast with much stronger outcomes in the post war period. In fact the latter are more in line with outcomes from studies using more recent time periods. 


\section{References}

Abowd, J.M. and D. Card. 1989. On the covariance structure of earnings and hours changes. Econometrica 57: 411-445.

Bain, G. S. and R. Price. 1980. Profiles of union growth. Oxford. Basil Blackewell.

Bernanke, B.S. 1986. Employment, hours, and earnings in the Depression: an analysis of eight manufacturing industries. American Economic Review 76: 82-109.

Bernanke, B.S. and J. Powell. 1986. The cyclical behavior of industrial labor markets: a comparison of the pre-war and post-war eras. In R.J. Gordon, ed., The American business cycle: continuity and change. Chicago: University of Chicago Press.

Bellmann, L. and U. Blien. 2001, Wage curve analyses of establishment data from Western Germany, Industrial and Labor Relations Review 54, 851-863.

Bils, M. 1985. Real wages over the business cycle: evidence from panel data. Journal of Political Economy 93: 666-689.

Borjas, G. J. 2002. Labor economics. Singapore: McGraw-Hill.

Brown, C. 1990. Firms' choice of method of pay. Industrial and Labor Relations Review 43, 165-S-182-S.

Devereux, P J. 2001. The cyclicality of real wages within employer-employee matches. Industrial and Labor Relations Review 54: 835-850.

Devereux, P J and R A Hart. 2006. Real wage cyclicality of job stayers, withincompany job movers, and between-company job movers. Industrial and Labor Relations Review (forthcoming).

Ehrenberg, R.G. 1971. Fringe benefits and overtime behavior, Massachusetts, Heath.

Fama, E F. 1991. Time, salary, and incentive payoffs in labor contracts. Journal of Labor Economics 9, 25-44.

Feinstein, C.H. 1972. National income, expenditure and output of the United Kingdom 1855-1965, Cambridge, Cambridge University Press.

Hart, R A. 2006. Worker-job matches, job mobility, and real wage cyclicality. Economica 73, 287-98.

Hart, R.A. and D.I.MacKay. 1975. Engineering earnings in Britain, 1914-68, Journal of the Royal Statistical Society (Series A) 138, 32-50. 
Hart, R.A. and T. Moutos. 1995. Human capital, employment and bargaining. London: Cambridge University Press.

Hill, T. P. and K.G.J.C. Knowles. 1956. The variability of engineering earnings, Bulletin of the Oxford University Institute of Statistics 18, 97-139.

Knowles, K.G.J.C. and Hill, T. P. 1954. The structure of engineering earnings, Bulletin of the Oxford University Institute of Statistics 16, 272-328.

Lazear, E.P. 1986. Salaries and piece rates, Journal of Business 59, 405-431.

Moulton, B. R. 1986. Random group effects and the precision of regression estimates. Journal of Econometrics 32: 385-397.

Pencavel, J. 1977. Work effort, on-the-job screening, and alternative methods of remuneration, Research in Labor Economics 1, 225-258.

Salop, S.C. 1979. A model of the natural rate of unemployment, American Economic Review 69, 117-125.

Seiler, E. 1984. Piece rate vs. time rate: the effect of incentives on earnings, The Review of Economics and Statistics 66, 363-376.

Solon, G R, Barsky, and J A Parker. 1994. Measuring the cyclicality of real wages: how important is composition bias? Quarterly Journal of Economics 109: 1 - 26

Shin, D. 1994. Cyclicality of real wages among young men. Economics Letters, 46,13742

Shin, D. and G. Solon. New evidence on real wage cyclicality within employeeemployer matches. Mimeo. University of Michigan.

Wigham, E. 1973. The power to manage. A history of the Engineering Employers' Federation. London: Macmillan. 
Table 1 Summary statistics and occupation/district definitions

\begin{tabular}{|c|c|c|c|c|c|c|}
\hline & \multicolumn{2}{|c|}{$1926-1966$} & \multicolumn{2}{|c|}{$1926-1938$} & \multicolumn{2}{|c|}{$1951-1966$} \\
\hline & Piecework & Timework & Piecework & Timework & Piecework & Timework \\
\hline $\begin{array}{l}\text { Mean number of workers per district (standard } \\
\text { deviation) }\end{array}$ & $\begin{array}{c}721 \\
(1208)\end{array}$ & $\begin{array}{c}512 \\
(1032)\end{array}$ & $\begin{array}{c}366 \\
(600)\end{array}$ & $\begin{array}{c}342 \\
(692)\end{array}$ & $\begin{array}{c}820 \\
(1513)\end{array}$ & $\begin{array}{c}549 \\
(1166)\end{array}$ \\
\hline Percentage pieceworkers to total workers & \multicolumn{2}{|c|}{59.0} & \multicolumn{2}{|c|}{56.4} & \multicolumn{2}{|c|}{60.2} \\
\hline $\begin{array}{l}\text { Mean percentage difference in piecework and } \\
\text { timework average hourly earnings }\end{array}$ & \multicolumn{2}{|c|}{25.4} & \multicolumn{2}{|c|}{32.0} & \multicolumn{2}{|c|}{15.9} \\
\hline Mean $\Delta \log$ (real weekly earnings) & $\begin{array}{c}0.025 \\
(0.052)\end{array}$ & $\begin{array}{c}0.027 \\
(0.042)\end{array}$ & $\begin{array}{c}0.022 \\
(0.067)\end{array}$ & $\begin{array}{c}0.028 \\
(0.052)\end{array}$ & $\begin{array}{c}0.024 \\
(0.038)\end{array}$ & $\begin{array}{c}0.026 \\
(0.033)\end{array}$ \\
\hline Mean $\Delta \log$ (real hourly earnings) & $\begin{array}{c}0.024 \\
(0.033)\end{array}$ & $\begin{array}{c}0.025 \\
(0.032)\end{array}$ & $\begin{array}{c}0.018 \\
(0.037)\end{array}$ & $\begin{array}{c}0.024 \\
(0.041)\end{array}$ & $\begin{array}{c}0.032 \\
(0.028)\end{array}$ & $\begin{array}{c}0.032 \\
(0.034)\end{array}$ \\
\hline
\end{tabular}

\section{Engineering Occupations:}

Coppersmiths; Fitters (other than skilled); Fitters (skilled); Toolroom Fitters; Machinemen (rated at or above fitter's rate);

Machinemen (rated below a fitter's rate); Machine Moulders (at or above moulder's rate); Machine Moulders (below a moulder's

rate); Moulding Machine Operators; Moulders (loose pattern); Patternmakers; Platers/Riveters/Caulkers; Sheet Metal Workers;

Turners; Labourers

\section{Engineering Districts:}

Aberdeen; Bedford; Birmingham; Blackburn; Bolton; Burnley; Burton; Coventry; Derby; Dundee; Halifax; Hull; Leicester;

Lincoln; Liverpool; London; Manchester; North East Coast; Northern Ireland; North Staffs; North West; Nottingham; Oldham;

Preston; Rochdale; St. Helens; Sheffield; West of England; Wigan 
Table 2 National and district unemployment change effects on real wages, real earnings and hours: 1926 - 1966 (Weighted Least Squares)

\begin{tabular}{|c|c|c|c|}
\hline \multicolumn{4}{|c|}{ Using national unemployment rate } \\
\hline & Piece rate pay & Hourly pay & $\begin{array}{l}\text { Significant } \\
\text { difference? }\end{array}$ \\
\hline Hourly earnings & $\begin{array}{l}-0.30 \\
(0.18)\end{array}$ & $\begin{array}{l}-0.06 \\
(0.21)\end{array}$ & No \\
\hline Hourly wage & - & $\begin{array}{c}0.10 \\
(0.19)\end{array}$ & - \\
\hline Weekly hours & $\begin{array}{l}-0.69^{* *} \\
(0.23)\end{array}$ & $\begin{array}{l}-0.88^{* *} \\
(0.25)\end{array}$ & No \\
\hline Weekly earnings & $\begin{array}{l}-1.00 * * \\
(0.32)\end{array}$ & $\begin{array}{l}-0.94^{*} \\
(0.39)\end{array}$ & No \\
\hline $\begin{array}{l}\text { Observations first-stage (second- } \\
\text { stage) }\end{array}$ & $3573(23)$ & $3904(23)$ & \\
\hline \multicolumn{4}{|c|}{ Using district unemployment rates } \\
\hline & Piece rate pay & Hourly pay & $\begin{array}{l}\text { Significant } \\
\text { difference? }\end{array}$ \\
\hline Hourly earnings & $\begin{array}{l}-0.25^{* *} \\
(0.06)\end{array}$ & $\begin{array}{l}-0.09 * \\
(0.04)\end{array}$ & Yes \\
\hline Hourly wage & - & $\begin{array}{l}-0.01 \\
(0.04)\end{array}$ & - \\
\hline Weekly hours & $\begin{array}{c}-0.51 * * \\
(0.16)\end{array}$ & $\begin{array}{c}-0.54 * * \\
(0.13)\end{array}$ & No \\
\hline Weekly earnings & $\begin{array}{l}-0.76^{* *} \\
(0.18)\end{array}$ & $\begin{array}{l}-0.63 * * \\
(0.13)\end{array}$ & No \\
\hline $\begin{array}{l}\text { Observations first-stage (second- } \\
\text { stage) }\end{array}$ & $3573(585)$ & $3914(611)$ & \\
\hline
\end{tabular}

Notes: Robust standard errors in parentheses under coefficients.

** (*) denotes two-tail significance at $0.01(0.05)$ level. 
Table 3 District unemployment change effects on real wages, real earnings and hours: pre- and postwar periods (Weighted Least Squares)

\begin{tabular}{|c|c|c|c|}
\hline \multicolumn{4}{|c|}{ Pre-war (1926 - 1938) } \\
\hline & Piece rate pay & Hourly pay & $\begin{array}{l}\text { Significant } \\
\text { difference? }\end{array}$ \\
\hline Hourly earnings & $\begin{array}{c}-0.29 * * \\
(0.06)\end{array}$ & $\begin{array}{l}-0.05 \\
(0.03)\end{array}$ & Yes \\
\hline Hourly wage & - & $\begin{array}{l}0.002 \\
(0.03)\end{array}$ & - \\
\hline Weekly hours & $\begin{array}{l}-0.43^{*} \\
(0.20)\end{array}$ & $\begin{array}{c}-0.51 * * \\
(0.14)\end{array}$ & No \\
\hline Weekly earnings & $\begin{array}{c}-0.72 * * \\
(0.22)\end{array}$ & $\begin{array}{c}-0.56 * * \\
(0.14)\end{array}$ & No \\
\hline $\begin{array}{l}\text { Observations first-stage (second- } \\
\text { stage) }\end{array}$ & $1908(312)$ & $2095(333)$ & \\
\hline \multicolumn{4}{|c|}{ Post-war (1951 - 1966) } \\
\hline & Piece rate pay & Hourly pay & $\begin{array}{l}\text { Significant } \\
\text { difference? }\end{array}$ \\
\hline Hourly earnings & $\begin{array}{l}-0.29 \\
(0.22)\end{array}$ & $\begin{array}{l}-0.52 * \\
(0.22)\end{array}$ & No \\
\hline Hourly wage & - & $\begin{array}{l}-0.33 \\
(0.20)\end{array}$ & - \\
\hline Weekly hours & $\begin{array}{c}-0.92 * * \\
(0.27)\end{array}$ & $\begin{array}{l}-0.46^{*} \\
(0.22)\end{array}$ & No \\
\hline Weekly earnings & $\begin{array}{c}-1.21 * * \\
(0.38)\end{array}$ & $\begin{array}{c}-0.99 * * \\
(0.35)\end{array}$ & No \\
\hline $\begin{array}{l}\text { Observations first-stage (second- } \\
\text { stage) }\end{array}$ & $2055(286)$ & $2113(286)$ & \\
\hline
\end{tabular}

Notes: Robust standard errors in parentheses under coefficients.

** (*) denotes two-tail significance at $0.01(0.05)$ level. 

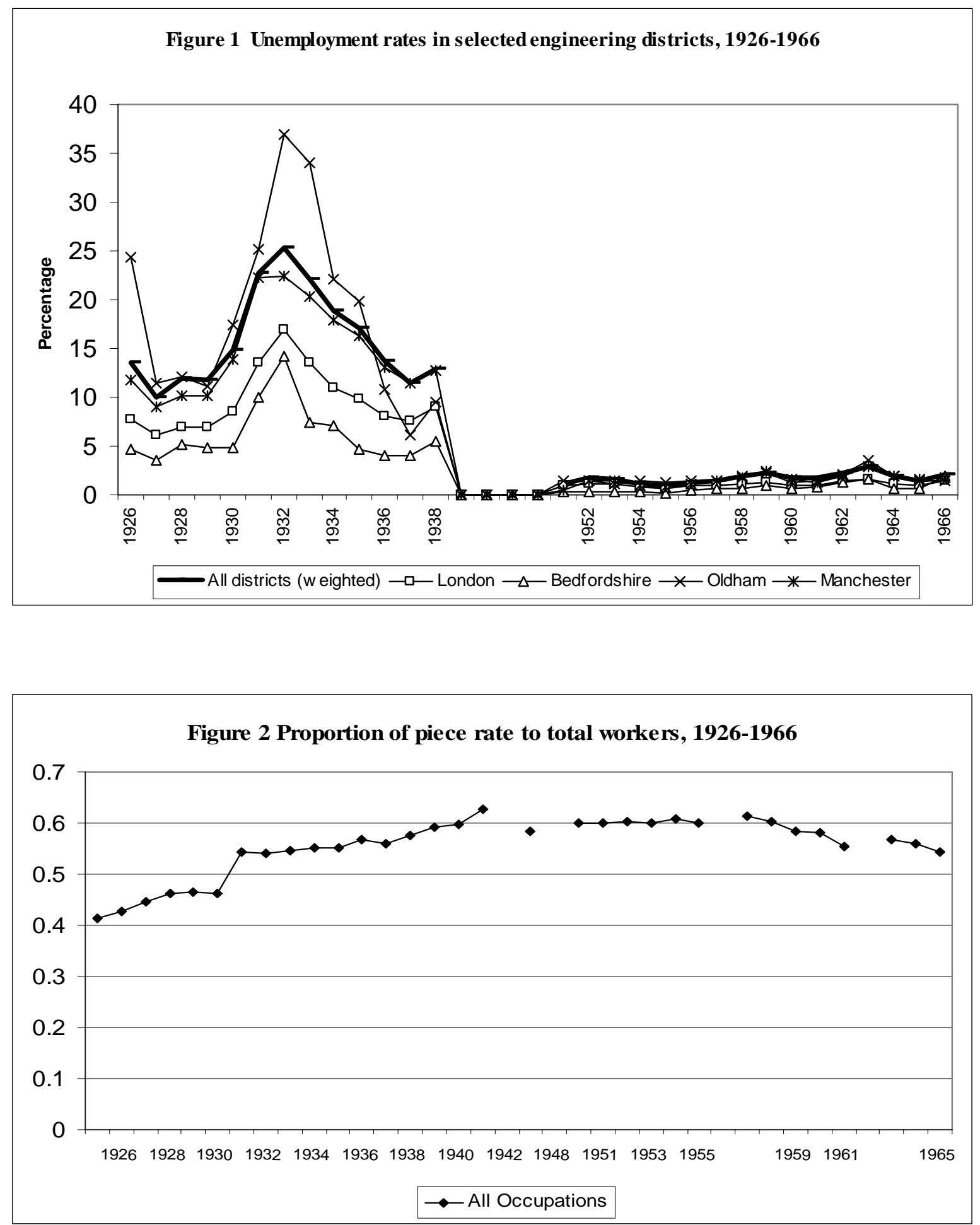


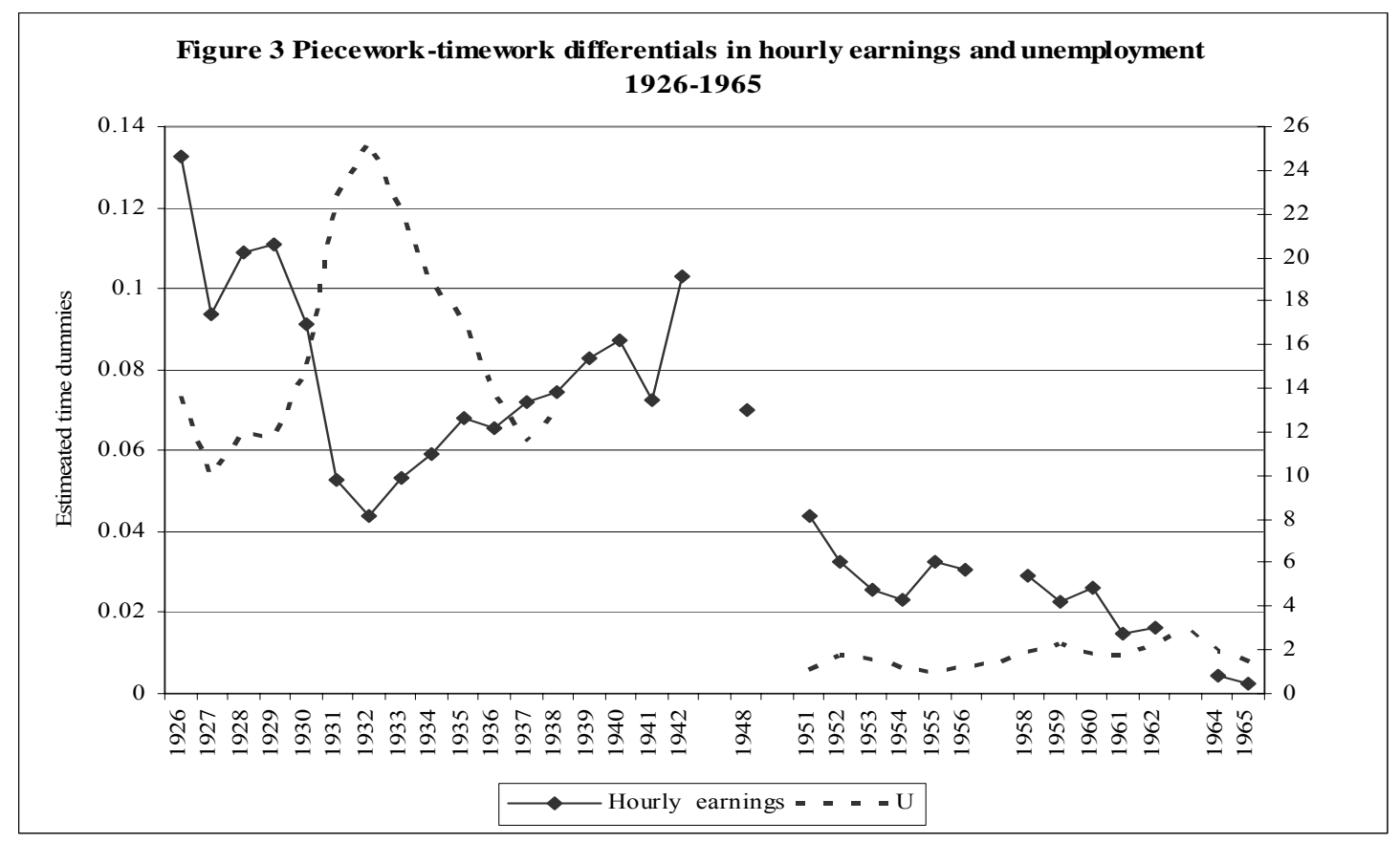

